\title{
Kas kui hästi tahta, võib iga teema tundlikuks muuta? Eesti õpetajate kogemused tundlike teemadega ajalootunnis
}

\author{
Katrin Kello ${ }^{\mathrm{a} 1}$, Maaris Raudsepp ${ }^{\mathrm{b}}$ \\ a Tartu Ülikooli ühiskonnateaduste instituut \\ ${ }^{b}$ Tallinna Ülikooli ühiskonnateaduste instituut
}

\begin{abstract}
Annotatsioon
Üks raskusi, millega tuleb õpetajatöös silmitsi seista, on ühiskondlikult tundlik õppesisu. Ajaloos ja muudes ühiskonnaainetes seostub see tihtipeale poliitiliste vastuolude ja valusate ajalookogemustega. Artiklis anname ülevaate tundlike ajalooteemade õpetamise teoreetilistest käsitlustest ning empiirilistest uurimustest nii ajaloodidaktika kui ka sotsiaalpsühholoogia vallas. Andmestik pärineb Eesti õpetajate küsitlusest, mis oli osa rahvusvahelisest koostööprojektist „Ajaloo representatsioonide sotsiaalpsühholoogiline dünaamika laienenud Euroopa Liidus“ kümne riigi osalusel. Veebiankeedi täitis 37 õpetajat, neist 13 vene keeles. Kogutud andmete temaatilisest kontentanalüüsist ja mõnel juhul ka statistilisest analüüsist ilmneb, milliseid ajalooteemasid tajuvad Eesti vastajad tundlikuna, mis strateegiaid nad kasutavad nende käsitlemisel, mis eesmärke endale seavad ning millist tuge vajavad.
\end{abstract}

Võtmesõnad: ajalooõpetus, õpetaja, tundlikud teemad, identiteet, sotsiaalne mälu, hariduse ühiskondlik-poliitiline kontekst

\section{Sissejuhatus}

Üks keerulisi ülesandeid õpetajatöös on tegelda tundliku õppesisuga. Õppeteema tundlikkus võib põhineda mitmesugustel teguritel alates õpetaja ja õpilaste isikutest ning lópetades ühiskondliku ja poliitilise kontekstiga. Viimasel juhul viitavad tundlikud teemad sellele, kuidas suhestuvad poliitiline kontekst, ühiskonnarühmade suhted ja ajalookujutlused tavateadvuses. Pole üllatav, et ühiskonnas vastandlikud positsioonid muudavad kõneaine tundlikuks ka klassiruumis. 
Uurimuses selgitame, milline on tundlike teemade laiem spekter Eesti ajalooõpetajate jaoks, sh kuivõrd domineerivad nende teemade seas varasemast teada, Eesti minevikuga seotud teemad (Kello, 2016; Oja, 2016; Pääbo, 2011), kuivõrd aga muud, näiteks päevakajalised ja globaalsed teemad. Iga teema, mida õpilased ja õpetajad tundlikuna kogevad - näiteks julmus, vägivald, orjapidamine -, ei pruugi olla ühiskondlikult vastuoluline. Teisalt võivad, aga ei pruugi ühiskonnas vastuolulised teemad olla tundlikud emotsionaalse teravuse mõttes. Neid võib siiski aineõpetuses tundlikuks pidada juhul, kui õpetajad või õpilased end neid käsitledes ebamugavalt tunnevad või nende käsitlemist lausa väldivad (vt nt Journell, 2013). Siinses uurimuses lähtume tundlike teemade võimalikult avatud määratlusest, et uurida, mis teemasid ülepea tajuvad Eesti õpetajad tundlikena ja miks, mis strateegiaid kasutavad nende käsitlemisel õppetunnis ning millist tuge vajavad. Arutluse alla võtame ka õpetajate tausta ning õppe-eesmärkide võimaliku mõju tundlike teemade käsitlemisele.

Teoreetiliselt sõltubki tundlike ja vastuoluliste teemade käsitlemine eesmärkidest, mida ajalooõpetusele seatakse (Goldberg, 2017). Laias plaanis võib neid eesmärke näha kahe pooluse - kognitiivsete ja akadeemiliste ning sotsiaalsete ja väärtuspõhiste eesmärkide - vahel paiknevana. Eri identiteetide tasakaalukas jõustamine, traumakogemuste läbitöötamine, sallivuse kujundamine teistsuguste ajalooperspektiivide suhtes, eetiline areng jms on kasvatuslikud eesmärgid, mida ajalooõpetus võib endale seada (nt Cooper \& Nichol, 2015; Euroclio, 2013; Rüsen, 2004). Tundlike teemade tark käsitlemine on üks eeldusi nende eesmärkide saavutamiseks. Samuti on väidetud, et õpilased peaksid õppima kriitiliselt analüüsima ja võrdlema minevikuesitusi eri paikades ja žanrites - kooliõpetusest meelelahutuse, poliitika ja meediani. Nad peaksid õppima nägema omaenda vaatenurka kui üht võimalikku ning aktsepteerima ka teiste arusaamade õigustatust, harjuma oma positsioonist vähemalt diskussiooni tarvis distantseeruma ja seda reflekteerima (nt Stradling, 2005; laiemalt sotsiaalainete kohta vrd Hess, 2009). Kriitilist mõtlemist toetavad lähenemisviisid soovitatakse ühendada empaatia- ja dialoogivõime arendamisega (Goldberg, 2016). Kriitilist mõtlemist eeldavate õppe-eesmärkide korral võib tundlike ja vastuoluliste teemade käsitlemises näha inspireerivat ülesannet, mis võib soodustada köitvat ja kaasavat õpetamist. On ju sellised teemad enamasti ka õpilaste jaoks nähtavalt relevantsed. Ühtlasi sunnivad nad õpetajat suuremale tähelepanule ja leidlikkusele, uute lähenemisviiside kasutamisele. Need lähenemisviisid vastavad ka Eesti ajaloo ainekavale, mis juba 1990. aastatest on rõhutanud mitmeperspektiivse, arutelusid ja kriitilist mõtlemist toetava käsitluse tähtsust (Oja, 2016).

Samas ei saa teemasid, mis seostuvad õpilastele ja õpetajatele lähedaste inimrühmade identiteedi ja juurdunud veendumustega, lahata sama kainelt 
distantseeritud viisil nagu akadeemilisi vastuolusid või ühiskonnas vastuolulisi, kuid õpilasi isiklikult vähem puudutavaid küsimusi (McCully, 2005; Zembylas \& Kambani, 2012). Arvestada tuleb ka õpilaste perekondlike arusaamadega. On teada, et perekond ja meedia kujundavad õpilaste minevikukujutusi erineval määral. Tavaliselt täiendavad kodust ja koolist saadavad ajalooteadmised teineteist vastuoludeta (nt Rantala, 2011). Samas võivad vähemusi esindavad õpilased, sõltuvalt enda ja oma pere kogemusest, minevikuhuvist ja meediatarbimisest, omandada kodus koolis õpitavaga võrreldes alternatiivseid minevikutõlgendusi. Juhtudel, kus nn kodune ajalugu on tugev, võivad õpilased nn kooliajaloo kas tagasi lükata või valida sealt välja just endale sobivama tõlgenduse ka mitmeperspektiivse lähenemisviisi korral (nt Hawkey \& Prior, 2011, vrd Tulviste, 1994).

Ainuõiget vastust, kuidas tundlike teemadega tegeleda, ei ole - palju sõltub kontekstist ja õpetaja tunnetusest. Ühelt poolt soovitatakse toetada empaatiat ja üksteisemõistmist näiteks narratiivide abil, mis võimaldavad teise perspektiivi sisse elada (Goldberg, 2016). Teisalt näitavad psühholoogilised uuringud valusate minevikusündmustega suhestumise kohta, et inimeste enesetunde kahjustamine mingi teema ettevaatamatul käsitlemisel võib ka mitmendas põlvkonnas tuua pigem kahju kui kasu, olgu siis tegemist ohvrite või süüdlaste järeltulijatega. Näiteks võib oma rühma poolt minevikus toime pandud ebaõiglusega tegelemine süüdlaste järeltulijate hulgas kutsuda esile erinevaid tundeid: nii valu, häbi kui ka kahetsust (Imhoff, Bilewicz, \& Erb, 2012) kui ka eitust, trotsi ja viha teise rühma vastu (Bilewicz \& Stefaniak, 2013). Samuti on näidatud, et lähem, sügavam ja laiem tundlike teemade käsitlemine võib isegi suurendada õpilaste toetumist oma identiteediga seotud positsioonidele (Goldberg, Schwartz, \& Porat, 2011; Stradling, 2005). Empaatia kujunemist konfliktis osalenud vastaspoole suhtes takistab gruppidevaheline nn võistlev ohvritunne (ingl competitive victimhood) - võrdlus vastaspoolega küsimuses, kumb pool on konfliktis rohkem kannatanud (Bar-Tal, Chernyak-Hai, Schori, \& Gundar, 2009). Niisiis tuleb ühelt poolt toetada eri vaatenurkade kriitilist vaagimist. Teisalt peab ópetajal olema takti ja tähelepanu õpilaste tunnete ja mõtete suhtes - ajalooõpetaja ongi erinevate seisukohtade tõlk ja vahendaja.

Varasemad õpetajate toimimisviiside uuringud on näidanud, et õpetajate strateegiad tundlike teemadega toimetulekuks ulatuvad täielikust vältimisest spetsiifiliste, just konkreetse teema (nt holokausti) jaoks välja töötatud meetodite kasutamiseni. Õpetajad rakendavad mitmesuguseid strateegiaid alates nurkade silumisest kuni tundlike aspektide süvitsi uurimiseni. On nii pigem ettevaatusmeetmetele keskenduvaid kui ka riskile minevaid õpetajaid (nt Kello, 2016; Kitson \& McCully, 2005). 


\section{Meetod}

\section{Uuringu taust}

Praegune uuring oli osa rahvusvahelisest koostööprojektist „Ajaloo representatsioonide sotsiaalpsühholoogiline dünaamika laienenud Euroopa Liidus“ (koostöövõrgustik COST) kümne riigi osalusel (Soome, Eesti, Iisrael, Austria, Saksamaa, Holland, Prantsusmaa, Itaalia, Valgevene, Serbia). Rahvusvaheline võrdlev analüüs on parajasti käsil. Selles artiklis analüüsime Eesti õpetajate vastuseid.

\section{Osalejad}

Vastajaid värvates püüdsime jõuda võimalikult paljude Eesti ajalooõpetajateni. Kasutasime erinevaid värbamisviise üldisest isiklikuni, sh ajalooõpetajate seltsi eesti- ja venekeelseid meililiste. Kuna varasematest uuringutest (Kello, 2016; Oja, 2016) on teada, et mitmeid teemasid tajuvad suhteliselt tundlikumana just vene emakeelega õpilasi õpetavad õpetajad, saatsime eraldi isiklikud e-kirjad kõigile vene õppekeelega koolis töötavatele ajalooõpetajatele, kelle meiliaadressid olid kooli kodulehel esitatud. Kutsusime küsitluses osalema ka ühe tundlike ajalooteemade koolituse osalejaid. Sellise värbamisviisiga taotlesime esinduslikkust nende õpetajate suhtes, kes oma töös ajalooteemasid tundlikuna tajuvad ning soovivad selle kohta oma kogemusi jagada. ${ }^{2}$ Nagu veebiküsitlused üldiselt, ei võimalda ka see küsitlus esinduslikkust kõigi Eesti ajalooõpetajate suhtes.

Mitme pöördumise tulemusel täitis ankeedi kokku 37 õpetajat, neist 24 eesti ja 13 vene keeles. Vastanud õpetajate vanus jäi 28 ja 65 aasta vahele (keskmine vanus 49), lisaks kuulus valimisse üks pensioneerunud üle 70aastane õpetaja. Vastajate hulgas oli 24 naist ja 13 meest. Osalejate staaž ajalooõpetajana oli keskmiselt 20 aastat, jäädes vahemikku 2-48 aastat. Enamasti olid osalejad ajalooõpetaja haridusega ajalooõpetajad, kes õpetasid peale ajaloo ka ühiskonnaõpetust (30 õpetajat). 14 õpetajat õpetas ajaloo kõrval ka üht või mitut muud ainet, mis ei olnud ühiskonnaõpetus. Enesemääratluselt oli osalejate hulgas enam-vähem võrdselt neid, kes tundsid ennast eelkõige ajalooõpetajana (17), ja neid, kes tundsid ennast võrdselt ajaloo ja mõne muu aine õpetajana (15). ${ }^{3}$ Vaid neli osalejat märkisid, et pole tundlikke teemasid isiklikult kogenud, või

\footnotetext{
Nagu veebiküsitluse puhul üldse, on ka praegusel juhul vastamise määra raske hinnata veebipõhiste küsitluste näol ongi tegemist n-ö ise, vastajate huvitatuse põhjal moodustuva valimiga. Seejuures ei ole võimalik kindlaks teha ka seda, kuivõrd paljude õpetajateni meie uuringukutse tegelikult jõudis, sest iga e-kirja saaja ei pruukinud kutset lugeda.

3 Vastus küsimusele „Kuivõrd Te tunnete ennast ajalooõpetajana?“. Vastusevariandid: „Ma õpetangi ainult ajalugu“, „Ma tunnen ennast peamiselt ajalooõpetajana“, „Ma tunnen ennast võrdselt ajaloo ja mõne muu aine õpetajana“, „Ma tunnen ennast peamiselt mõne muu aine õpetajana“, „Ma ei pea ennast üldsegi ajalooõpetajaks“.
} 
eitasid selliste teemade olemasolu põhimõtteliselt. Kuna niisuguse kogemuseta õpetajaid on kindlasti rohkem kui meie valimis, võib öelda, et uuringus osalesid eeskätt õpetajad, kellele teema oli isiklikult tähtis.

Osalejad õpetasid enamasti 11-19aastaseid õpilasi kas klassides, kus õppisid valdavalt eesti emakeelega õpilased (8 õpetajat), rohkem või vähem etniliselt segatud klassides (11 õpetajat, kelle hinnangul mitte-Eesti päritolu õpilasi oli vähemalt $5 \%)^{4}$ või vene emakeelega õpilastele suunatud koolides, s.o endistes vene õppekeelega koolides (20 õpetajat). Kaks eesti emakeelega õpetajat õpetas ühtaegu nii eesti kui ka vene emakeelega õpilastele suunatud koolis. Tabel 1 näitab eesti ja vene emakeelega vastajate osakaalu eesti või vene emakeelega õpilastele suunatud koolide kaupa. Niisiis on vene emakeelega õpilasi õpetavaid õpetajaid vastajate hulgas märksa rohkem kui Eesti ajalooõpetajate seas tervikuna (venekeelsetele õpilastele suunatud koolides õpib umbes viiendik Eesti õpilasi).

Tabel 1. Eesti ja vene emakeelega vastajad eesti või vene emakeelega õpilastele suunatud koolide kaupa

\begin{tabular}{l|c|c}
\hline & $\begin{array}{c}\text { Eesti emakeelega vastajad } \\
(N=23)\end{array}$ & $\begin{array}{c}\text { Vene emakeelega vastajad } \\
(N=14)\end{array}$ \\
\hline $\begin{array}{l}\text { Eesti emakeelega õpilastele } \\
\text { suunatud koolis }(N=18)\end{array}$ & 19 & 0 \\
\hline $\begin{array}{l}\text { Vene emakeelega õpilastele } \\
\text { suunatud koolis }(N=20)\end{array}$ & 6 & 14 \\
\hline
\end{tabular}

Osalejad töötasid peamiselt „tavalises üldhariduskoolis“ (28 õpetajat), kus õppisid keskmise sotsiaal-majandusliku taustaga õpilased (23 õpetajat). Uuringus osalesid ka mõned „Eesti mõistes eliitkooli“ ja täiskasvanute gümnaasiumi õpetajad, samuti erakoolis ja liitklassidega põhikoolis töötav õpetaja.

\section{Ankeet ja vastuste analüïs}

Eestis korraldati küsitlus veebis eesti ja vene keeles 2015. a sügisel ja 2016. a kevadel. Kokku sisaldas ankeet 127 tunnust. Nagu juba eespool öeldud, keskenduti küsitluses tundlikele teemadele võimalikult laialt, andmata ette

4 Eesti emakeelega õpilastele suunatud koolides (s.o enne varasemate vene õppekeelega koolide üleminekut osalisele eestikeelsele aineõppele „eesti õppekeelega koolides“) töötavate õpetajate hinnangul ulatus vene või muu mitte-eesti kodukeelega õpilaste osakaal maksimaalselt 40\%-ni. Õpilaskollektiivides, kus mitte-eesti kodukeelega õpilasi oli üle 5\%, oli nende osakaal kõige sagedamini hinnanguliselt 10\%. 
tundlikkuse määratlust. Avatud ja suletud küsimused puudutasid võimalikke tundlikke teemasid, tundlikkuse olemust ja tegureid, tundliku teema õpetamisel kasutatavaid meetodeid, ainealaseid ja pedagoogilisi veendumusi. Seejuures sisaldas ankeet üheksat avatud küsimust tundlike teemade või nende õpetamise kohta. Kuna osale neist vastas enamik osalejaid, sealhulgas pikemate refleksioonidena, andis küsitluse kvalitatiivne osa rikkalikku materjali.

Andmete analüüsis kombineerime kvalitatiivset (temaatilist) ja kvantitatiivset (kirjeldava statistika meetodeid kasutavat) uurimisviisi. Analüüsi kvalitatiivne osa toetub temaatilisele analüüsile (Braun \& Clarke, 2006). Analüüsitulemusi illustreerime näitlike tsitaatidega. Vastajatele viitame numbri ning ankeedi keelele osutava E- või R-tähe abil.

Andmete kvantitatiivne analüüs toetub kirjeldavale statistikale. Õppe-eesmärkide tähtsusele antud hinnangute grupeerimiseks kasutasime uurimuslikku faktoranalüüsi (peakomponentide meetod, varimaks-pööramisega).

\section{Tulemused ja arutelu}

\section{Põhilised valukohad ja tundlikkuse põhjused}

Põhilisi valukohti ja tundlikkuse põhjuseid võimaldab küsimustik hinnata kahel viisil. Esiteks on vastajate hinnanguid seitsmele etteantud teemale võimalik kirjeldada kvantitatiivselt. Teiseks pakuvad avatud küsimuste vastused, mille korral said vastajad nii ise teemasid esitada kui ka nende keerukuse aspekte pikemalt põhjendada, võimalust kvalitatiivseks analüüsiks.

Kvantitatiivse elemendina sisaldas ankeet seitset etteantud teemat: 1. Vabadussõda ja Eesti riigi loomine; 2. Eesti iseseisvuse kaotamine aastatel 1939-1940; 3. Teine maailmasõda; 4. Eestlaste osalemine julmades tegudes (nt Vabadussõjas ja muudes sõdades, kü̈̈ditamistes, holokaustis); 5. Nõukogude aeg ja nõukogude korra olemus, külm sõda; 6. Immigratsioon, rahvusvähemused; 7. Areng pärast aastat 1991. Kõik teemad seostuvad rohkem või vähem otsesõnu seniste Eesti riiklike ajaloo ainekavade teemadega ning lähtuvad nii varasemas uuringus (Kello, 2016; Oja, 2016) ilmnenust kui ka püüdest saavutada rahvusvahelist võrreldavust laiema uuringu raames. Iga teema kohta palusime vastata kolmele küsimusele: „Kuivõrd tundlikuna olete seda teemat oma praktikas kogenud?", „Kui sageli olete seda teemat tegelikult ise õpetanud?" ning „Milline on Teie mulje: kui paljude Eesti õpetajate kogemuses võiks see teema olla tundlik?". Joonis 1 näitab hinnanguid etteantud teemadele a) teiste õpetajate võimaliku kogemuse ning b) iseenda tegeliku kogemuse seisukohalt. 

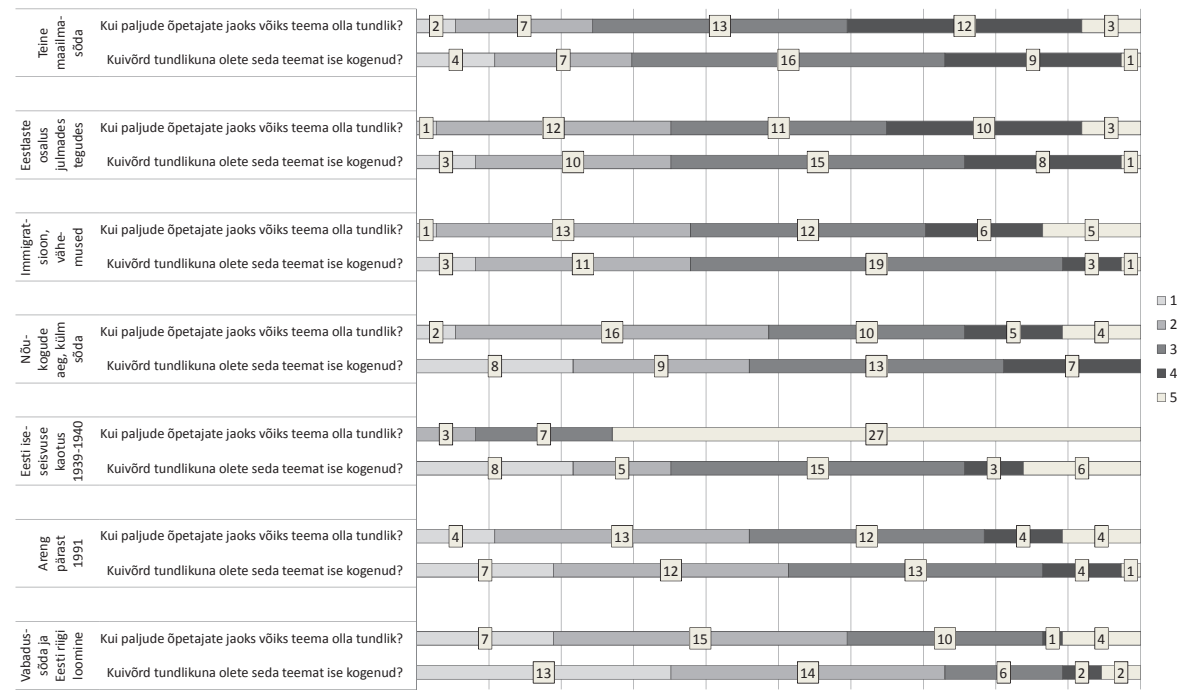

Joonis 1. Hinnangud etteantud teemade ${ }^{5}$ tundlikkusele: 1 - „pigem mitte kellegi jaoks" või „üldse mitte“, 4 - „paljude jaoks" või „väga“, 5 - „raske öelda“ või vastamata $(N=37$, absoluutarvud)

Joonisel nähtavaid tulemusi aitavad avada õpetajate sõnalised vastused, mida käsitleme allpool. Vastuste jaotumine tundub joonist vaadates mõistetav. Üllatav võib olla vaid teema „Eesti iseseisvuse kaotus 1939-1940“ pigem madal positsioon ning anomaaliana torkab just selle teema puhul silma vastuse „raske öelda" tavatult suur osakaal. Ühelt poolt võib see olla võrreldes teistega pigem hästi läbi arutatud teema, mille kohta on olemas suhteliselt rohkem materjali, nii et see teema ei tundu õpetajatele (enam) keerulisena. Teisalt on teema tundlikkus üldtuntud (vrd Kello, 2016; Oja, 2016) ning kolleegide kogemusi julgetakse seetõttu suhteliselt vähem hinnata enda kogemusest lähtudes. Kuna spontaansetes vastustes, mida vaatleme järgnevalt, oli Nõukogude okupatsioonide kontekstis mõistega okupatsioon seotu sageduselt teisel kohal (tabel 2), on võimalik, et selle teema puhul eristasid vastajad selgemini tundlikkust õpilaste versus iseenda jaoks.

Küsimustikus palusime õpetajatel hinnata ka joonisel 1 toodud teemade õpetamise sagedust. Kõige sagedamini õpetasid vastajad teemasid „Teine maailmasõda" ning "Nõukogude aeg ja nõukogude korra olemus, külm sõda“ (vastavalt 35 ja 34 vastajat märkisid „regulaarselt“). Kahele viimasele kohale jäid „Eestlaste osalus julmades tegudes“ ning „Immigratsioon, rahvusvähemused“ (vastavalt 27 ja 26 vastajat märkisid „regulaarselt“).

Küsimused „Milline on Teie mulje: kui paljude Eesti õpetajate kogemuses võiks see teema olla tundlik?", „Kuivõrd tundlikuna olete seda teemat oma praktikas kogenud?“. 
Tabel 2. Spontaanselt mainitud teemade kategooriad ${ }^{6}$

\begin{tabular}{l|c|l}
\hline $\begin{array}{l}\text { Teema } \\
\text { kategooria }\end{array}$ & $\begin{array}{c}\text { Maininud } \\
\text { vastajate } \\
\text { arv }^{7}\end{array}$ & Näited \\
\hline
\end{tabular}

\section{Päevakajalised ja globaalsed teemad (kokku 15 vastajat)}

\begin{tabular}{|c|c|c|}
\hline $\begin{array}{l}\text { 1.1. Julmus, vägi- } \\
\text { vald üldiselt kui } \\
\text { laste jaoks rasked } \\
\text { teemad }\end{array}$ & 2 & $\begin{array}{l}\text { Julmus sõdades; Genotsiid, holokaust; Korruptsioon poliitikas } \\
\text { ja majanduses [...] Rasked teemad, mida on raske mõista. } \\
\text { Võivad tekitada isegi psühholoogilisi probleeme. [...] } \\
\text { Vägivald naiste suhtes sõdades ja vangilaagrites (E11) }\end{array}$ \\
\hline $\begin{array}{l}\text { 1.2. Aktuaalsed } \\
\text { kriisid või sõjad } \\
\text { (Ukraina, Süüria, } \\
\text { Lähis-lda) }\end{array}$ & 4 & $\begin{array}{l}\text { Mõni teema võib muutuda ka tundlikuks tingituna poliiti- } \\
\text { listest oludest ja meedia tegevusest, s.t. teema traditsiooni- } \\
\text { liselt justkui tundlik ei peakski olema, aga siis järsku on (nt } \\
\text { Ukraina ja Krimm) jne. (E18) }\end{array}$ \\
\hline $\begin{array}{l}\text { 1.3. Pagulaste } \\
\text { küsimus: päeva- } \\
\text { kajalisus, tund- } \\
\text { likkus Eesti ühis- } \\
\text { konnas }\end{array}$ & 6 & $\begin{array}{l}\text { Pagulasteema nii lähiajaloo kui ühiskonnaõpetusega seoses. } \\
\text { Moslemid Eesti ühiskonnas on samuti üsna tundlik teema. } \\
\text { (E6) }\end{array}$ \\
\hline 1.4. Terrorism & 2 & Teadmatus, eelarvamused, hirm terrorismi ees. (E11) \\
\hline $\begin{array}{l}\text { 1.5. Kolonialismi } \\
\text { ja Kolmanda } \\
\text { Maailmaga } \\
\text { seotud teemad }\end{array}$ & 2 & $\begin{array}{l}\text { Koloniseerimine, orjanduse küsimus, islami teke ja levik. } \\
\text { Tundlikud [on need teemad] õpilaste jaoks, eriti just tänases } \\
\text { poliitilises olukorras. Õpilased lähenevad nendele teemadele } \\
\text { eelarvamustega, mida on tihti raske murda. (E20) }\end{array}$ \\
\hline $\begin{array}{l}\text { 1.6. Religioon kui } \\
\text { selline, religiooni } \\
\text { ajalugu }\end{array}$ & 5 & $\begin{array}{l}\text { Tänapäeval on väga erinevat usku õpilasi klassides, kes } \\
\text { oskavad õpetaja selgitustele midagi huvitavat lisada. Teistele } \\
\text { tundub iga usundi, ka ajalooliste usundite tundmaõppi- } \\
\text { mine usulise propagandana. Kuigi neile on selgitatud, et } \\
\text { me vaatleme neid usundeid vaid läbi ajaloolis-kultuurilise } \\
\text { vaatenurga. (E7) }\end{array}$ \\
\hline
\end{tabular}

6 Eristatud on teemasid, mida mainis vähemalt kaks vastajat. Arvestatud on vastuseid järgmistele avatud küsimustele ankeedi eri sektsioonides: (1.1) „Kas olete kogenud mõnd ajalooteemat oma õpetajapraktikas tundlikuna? Palun kirjutage vähemalt kaks“; (1.2) „Kuidas (mis mõttes) on need teemad tundlikud? Tundlikud kelle jaoks ja mispärast?"; (2.1) [etteantud teemade ploki järel] „Kas Teile meenub nüüd veel ka teisi selliseid teemasid? Palun kirjutage kuni kolm“; (2.2) „Kuidas (mis mõttes) on need teemad tundlikud? Tundlikud kelle jaoks ja mispärast?“; (3) „Palun kirjutage siia üks tundlik teema, mille käsitlemist Te tegelikult kaalusite, kuid mille õpetamisest kas loobusite või mille suhtes tundsite end ebakindlalt"; (4) „Milline on Teie arvamus - kas Eesti ajaloos on mõni tähtis teema, mis on unustatud, õppekavas tähelepanuta jäetud või mille unustamist soodustatakse poliitilistel põhjustel?"; (5) „Kas sooviksite saada (veel) mingisugust täienduskoolitust seoses tundlike teemadega?"; (6) „Kas sooviksite kirjeldada lühidalt mõnda ajalootundi, kus käsitlesite tundlikku teemat?”. Igal real on iga vastajat arvestatud üks kord. Sama vastus võib olla kodeeritud mitmes kategoorias. 


\begin{tabular}{l|c|l}
\hline $\begin{array}{l}\text { Teema } \\
\text { kategooria }\end{array}$ & $\begin{array}{c}\text { Maininud } \\
\text { vastajate } \\
\text { arv }^{7}\end{array}$ & Näited \\
\hline $\begin{array}{l}\text { 1.7. Rahvus- } \\
\text { vahelised suhted } \\
\text { globaalsel tasan- } \\
\text { dil; suurvõimude } \\
\text { suhted külma } \\
\text { sõja ajal ja hiljem }\end{array}$ & 2 & $\begin{array}{l}\text { USA välispoliitika 20. sajandi lõpus ja 21. sajandi algul. (R5) } \\
\text { Suurvõimude vastasseis ja külm sõda. (R7) }\end{array}$ \\
\hline
\end{tabular}

\section{Eesti ja Vene ajalooga seotud teemad (kokku 30 vastajat)}

\begin{tabular}{|c|c|c|}
\hline $\begin{array}{l}\text { 2.1. Liivi sõda ja/ } \\
\text { või Põhjasõda }\end{array}$ & 3 & $\begin{array}{l}\text { Erinevad venelaste vägivallaga seotud teemad: Liivi sõda, } \\
\text { Põhjasõda; mõlemas neist küüditamise ja musta maa taktika } \\
\text { teemas jne. [...] Vahel on ka nende teemade juures mõni } \\
\text { ópilane päris teravalt reageerinud. (E1) }\end{array}$ \\
\hline $\begin{array}{l}\text { 2.2. Venestamine } \\
\text { (19. sajandi } \\
\text { lõpus ja/või } \\
\text { nõukogude } \\
\text { perioodil), } \\
\text { sellele antavates } \\
\text { hinnangutes } \\
\text { sisalduv topelt- } \\
\text { moraal (võrrel- } \\
\text { des venekeelsete } \\
\text { koolide eestista- } \\
\text { misega) }\end{array}$ & 4 & $\begin{array}{l}\text { [Venestamist 19. sajandil] käsitlevad meie õpikud selgelt } \\
\text { negatiivse nähtusena. Kirjeldatakse venestamise mõju } \\
\text { haridusele jms. Kuidas minna selle teemaga venekeelse } \\
\text { auditooriumi ette, kui nad peavad (sic!) seda õppima eesti } \\
\text { keeles? (E1) } \\
\text { Paljusid ajaloosündmusi nähakse üksnes eestlaste kui riigi- } \\
\text { rahvuse vaatevinklist. [...] Näiteks Jaan Tõnisson on „õige } \\
\text { mees", sest ta toetas Eesti asja, vastustas venestust, arendas } \\
\text { eestikeelset kooliharidust jne, samas kui praegusi vene- } \\
\text { keelsete koolide toetajaid peetakse parimal juhul siiralt } \\
\text { eksiteel olevateks isikuteks, halvimal juhul aga Kremli } \\
\text { agentideks. (R4) }\end{array}$ \\
\hline $\begin{array}{l}\text { 2.3. Vabadus- } \\
\text { sõda, Tartu rahu }\end{array}$ & 3 & $\begin{array}{l}\text { Tartu rahu piirid ja praegused kontrolljooned. Miks pool- } \\
\text { datakse ikka nn impeeriumi taastamist [...] Kas piirid on } \\
\text { poliitilised või peaksid olema pigem etnilised? (E22) } \\
\text { Vabadussõda (koolipoiste patriootlikkus) [...] Need on emot- } \\
\text { sionaalselt väga rasked: emotsionaalselt on raske teemat } \\
\text { selgitada ja õpilastel ka teemaga tegeleda. (E12) }\end{array}$ \\
\hline $\begin{array}{l}\text { 2.4. Vapside liiku- } \\
\text { mine ja/või Pätsi } \\
\text { režiim kui liiga } \\
\text { vähe tähelepanu } \\
\text { leidev teema }\end{array}$ & 2 & $\begin{array}{l}\text { Vapsid, 1934. aasta sõjaväeline riigipööre ning Pätsi } \\
\text { heroiseerimine [kui liiga vähe tähelepanu leidev teema]. } \\
\text { (E14) }\end{array}$ \\
\hline $\begin{array}{l}\text { 2.5. Nõukogude } \\
\text { okupatsiooni(de) } \\
\text { ga seotud sünd- } \\
\text { mused Eestis } \\
(1939 / 40 \text { ja/või } \\
1944)\end{array}$ & 17 & $\begin{array}{l}\text { Eesti okupeerimine - kas oli või ei olnud. [...] venekeelse } \\
\text { ópilase jaoks: sõna okupatsioon, okupant, sissetungija - } \\
\text { seda võetakse isiklikult (E19) } \\
\text { Kuna Eesti elanikkond reageeris sündmustele 1939-1940 } \\
\text { küllalt vaoshoitult, siis on väga raske ühemõtteliselt nõustuda } \\
\text { terminiga "nõukogude okupatsioon" (R1) }\end{array}$ \\
\hline
\end{tabular}




\begin{tabular}{|c|c|c|}
\hline $\begin{array}{l}\text { Teema } \\
\text { kategooria }\end{array}$ & $\begin{array}{l}\text { Maininud } \\
\text { vastajate } \\
\text { arv }^{7}\end{array}$ & Näited \\
\hline $\begin{array}{l}\text { 2.6. Muu Teise } \\
\text { maailmasõja } \\
\text { ajal peamiselt } \\
\text { Eestiga seotud } \\
\text { aspektid (sh } \\
\text { sõjakuriteod, } \\
\text { holokaust) }\end{array}$ & 19 & $\begin{array}{l}\text { Pereliikmete või esivanemate osalemine erinevates } \\
\text { armeedes (E11) } \\
\text { Väga vähe on räägitud sellest, kes kannatas kõige sõjas } \\
\text { tegelikult kõige rohkem ja tänu kellele natsism Saksamaal } \\
\text { purustati. (R5) } \\
\text { Vene õpilased arutavad kodus Teist maailmasõda ning aja- } \\
\text { lootunnis ei nõustu nad Eesti autorite seisukohaga; nad arva- } \\
\text { vad, et nõukogude sõdur on vabastaja. (R6) }\end{array}$ \\
\hline $\begin{array}{l}\text { 2.7. Metsa- } \\
\text { vennad }\end{array}$ & 3 & $\begin{array}{l}\text { Metsavennad - partisanid või bandiidid? (R4) } \\
\text { Metsavennad [...] Kui õpilase perekonnas on keegi olnud } \\
\text { seotud metsavendlusega. (E6) }\end{array}$ \\
\hline $\begin{array}{l}\text { 2.8. Küüditamine } \\
1941 / 1949\end{array}$ & 4 & $\begin{array}{l}\text { Õpilaste hulgas on nii küüditatute kui ka küüditajate } \\
\text { järeltulijaid ja paiksed inimesed teavad-tunnevad mitmeid } \\
\text { põlvkondi. (E4) } \\
\text { Küüditamise teema - eriti kui klassis on lapsed vene pere- } \\
\text { kondadest. [...] Vene taustaga õpilastes võivad need teemad } \\
\text { põhjustada segadust või piinlikkust, aga samuti trotsi ja } \\
\text { solvumist. (E6) }\end{array}$ \\
\hline $\begin{array}{l}\text { 2.9. Nõukogude } \\
\text { aeg (ENSV) kui } \\
\text { periood, selle } \\
\text { tähendus }\end{array}$ & 11 & $\begin{array}{l}\text { Praegune põlvkond ei saa sellest absurdiajast aru. (E15) } \\
\text { [Õpilastel tekib] tihti tunne, et nemad ongi siis siin ajaloos } \\
\text { pahad, kuid NSVL paha oli, sest nemad esindavad vene } \\
\text { rahvust. (E20) }\end{array}$ \\
\hline $\begin{array}{l}\text { 2.10. } 1980 . \\
\text { aastate lõpp, } \\
\text { Nõukogude Liidu } \\
\text { lagunemine, } \\
\text { Eesti iseseisvuse } \\
\text { taastamine }\end{array}$ & 5 & $\begin{array}{l}\text { 80. aastate lõpu sündmused [...] Täiskasvanud õppurite } \\
\text { hulgas on neid, kes ise osalesid ja väidavad, et õpiku käsitlus } \\
\text { on liialdatud. (E2) } \\
\text { Suhteliselt raske on haarata vene õpilasi laulva revolutsiooni } \\
\text { ja iseseisvuse teemasse, kui laulva revolutsiooni ajal kujutati } \\
\text { seda rahvusgruppi kui vaenlast (migrandid). Peale iseseisvu- } \\
\text { mist jäi suur osa nende rahvusgrupist õigusteta. (E5) }\end{array}$ \\
\hline $\begin{array}{l}\text { 2.11. Eesti ühis- } \\
\text { kond pärast taas- } \\
\text { iseseisvumist, } \\
\text { venekeelse vähe- } \\
\text { muse praeguse } \\
\text { positsiooniga } \\
\text { seotu }\end{array}$ & 5 & $\begin{array}{l}\text { Eesti rahvuslik koosseis ja nende erinevad teod/omadused/ } \\
\text { tagajärjed. [...] Erinevad rahvad ja nende kooseksisteerimise } \\
\text { võimalused. Tundlik teema teinekord erinevast rahvusest } \\
\text { ópilastele. (E22) } \\
\text { Mõnede 1991. aastale järgnenud otsuste järelmitel (Eesti } \\
\text { valitsuse keeldumine tagada suurele osale venekeelsest } \\
\text { elanikkonnast tingimusteta kodakondsust) on endiselt suur } \\
\text { mõju sellele, kuidas mõned õpilased Eestit näevad. (R1) }\end{array}$ \\
\hline $\begin{array}{l}\text { 2.12. Venelaste } \\
\text { jm mitte-eest- } \\
\text { laste ja/või Vene- } \\
\text { maa positiivne } \\
\text { roll Eesti ajaloos }\end{array}$ & 5 & $\begin{array}{l}\text { Vene kultuuritaustaga inimeste ajaloo lõimimine eesti ajaloo- } \\
\text { narratiivi, neutraalselt. Ränne siia, eelnev kultuurautonoomia } \\
\text { jne [kui liiga vähe tähelepanu leidvad teemad] (E5) } \\
\text { mitte-eestlaste panus eesti kultuuri ja iseseisvumise käiku } \\
\text { [kui liiga vähe tähelepanu leidev teema] - infopuudus } \\
\text { valitseb ennekõike eesti keeles! (R2) }\end{array}$ \\
\hline
\end{tabular}


Vastates avatud küsimustele (ankeedis paluti korduvalt nimetada ja põhjendada tundlikke teemasid), nimetas 32 osalejat vähemalt ühe tundliku teema. Ühele osalejale ei tulnud konkreetne teema spontaanselt meelde, küll aga kirjutas ta tundlikkuse põhjustest. Vaid neli osalejat märkisid, et pole tundlikke teemasid isiklikult kogenud, või lausa eitasid selliste teemade olemasolu. Tabel 2 annab ülevaate avatud vastuste induktiivsel rühmitamisel moodustunud teemadest. Oleme siin arvestanud nii selliseid teemasid, mida õpetajad nimetasid otsesõnu tundlikeks või mille õpetamisel tundsid nad end ebakindlalt, kui ka selliseid, mille nad tõid välja õppekavas või Eesti ühiskonnas küllaldase tähelepanuta jäetuna või meelega unustatuna. Järgnevalt vaatame lähemalt levinuimaid teemade tüüpe ja tundlikkuse aspekte. Tekstisiseseid tsitaate lisame juhul, kui mõnd teemat ja näiteid ei ole tabelis eraldi esitatud.

Päevakajaliste ja globaalsete, laste jaoks üldiselt raskete teemade hulgas, mida õpetajad mainisid, olid sõda Ukrainas ja Süürias ning muud Lähis-Ida sündmused, pagulased, immigratsioon, islami temaatika. Viimane paistab olevat muutunud aktuaalseks seoses ISi, terrorismi ja võimalik et ka põgenikekriisiga (tabeli read 1.1-1.7). Samas võis religioon (rida 1.6) osutuda tundlikuks ka n-ö iseenesest. Ühelt poolt võis see tuleneda mõne õpilase arusaamast, et igasugune religioonist räkikimine on usuline propaganda. Teisalt võis mõnes õpilases negatiivset reaktsiooni esile kutsuda kokkupuude teistsuguse religioonikäsitusega kui see, millega ta oli harjunud kodus. Samas võisid usklikest peredest pärit õpilased õpetaja esitatud teadmisi ka täiendada. Mitu õpetajat mainis kolonialismi, Kolmanda Maailma ja orjanduse teemat (rida 1.5). Tundlikuna nimetati ka laste tööjõudu, korruptsiooni poliitikas ja majanduses, sõjakuritegusid, sõjaaegset vägivalda (rida 1.1). Sellised teemad põimivad mineviku problemaatikat tänapäevaga ja vastupidi. Mainiti ka Türgi genotsiidi Armeenias, USA ja NSVLi suhteid, USA välispoliitikat alates 20. sajandi lõpust. Üldiselt võib nimetatud päevakajaliste ja globaalsete teemade kohta öelda, et need puudutavad kas vägivalla kasutamist või konflikte, milles vastanduvad erinevad huvid ning mille kohta ei ole välja kujunenud ühtseid hinnanguid.

Päevakajaliste teemade omaette alaliik oli n-ö kohalik päevakajalisus, Eesti ja Vene mineviku ning eestlaste ja venelaste suhete tõlgendamisega seotud temaatika. Kuigi näiteks nõukogude ajaga seoses mainiti ka mitte otseselt venelastega seotud küsimusi (näiteks kunagisele komparteisse kuulumisele antava hinnangu jätkuvat aktuaalsust (E4)), domineerisid selles rühmas selgelt EestiVene perspektiivierinevust esile toovad, vene õpilaste identiteeti ja Eesti tänapäevast ühiskonnakorda puudutavad teemad. Täpsemalt võeti vaatluse alla Eesti, Vene ja nõukogude minevikuga seotud sündmuste erinev tajumine õpilaste poolt ning vastuolulised esitused õpikutes, meedias ja avalikkuses. 
Näiteks mainis mitu õpetajat eestikeelse avalikkuse ning ka õpikute hinnangutes sisalduvat topeltmoraali, vähemalt õpilaste perspektiivist, ning sellest tulenevat ebaõiglustunnet - eriti seoses venestusega, mis vene emakeelega õpilaste jaoks seostub paratamatult venekeelsete koolide eestistamisega (rida 2.2). Mõned õpetajad mainisid topeltmoraali seisukohalt ka pronksiöö tõlgendamist võrdluses 1980. aasta noorterahutusega. Näiteks võib mõlema sündmuse puhul küsida, kummaga oli tegu: kas rahvusliku eneseteadvuse sähvatuse või huligaansusega (R4).

Korduvalt mainiti Venemaa ja venelaste negatiivse rolli ühekülgset rõhutamist Eesti ajaloos - tähelepanek, mida toetavad ka olemasolevad õpikuanalüüsid (vrd nt Pääbo, 2011). Sama mündi teiseks pooleks on vähene tähelepanu etniliste vähemuste või venelaste positiivsele rollile - võrreldes selle temaatika tajutud tähtsusega - Eesti ajalookäsitustes, olgu õpikutes või avalikkuses. Vastates avatud küsimusele, kas Eesti ajaloos on mõni tähtis teema, mis on unustatud, õppekavas tähelepanuta jäetud või mille unustamist soodustatakse poliitilistel põhjustel, leidis neli vastajat, et selliste teemade hulka kuulub venelaste ja Venemaa positiivne roll Eesti ajaloos (tabeli rida 2.12).

Teisalt tõi mitu õpetajat välja Vene meedia ja ajaloopoliitika mõju õpilaste ja lapsevanemate vaadetele. Eesti eestlaste ja venelaste sotsiaalne mälu avaldus tähelepanekus, et vanemad mäletavad nõukogude aega teisiti, kui on kombeks praeguses Eesti peavooludiskursuses (rida 2.9). Nõukogude perioodi kui tundliku teema põhjendustes torkab silma erinevaid õpilasi õpetavate õpetajate põhjenduste erinevus. Kui vene emakeelega õpilaste koolis või eesti ja vene emakeelega õpilaste segaklassis õpetavad vastajad rõhutasid eespool mainitud asjaolusid, nagu vene õpilaste teistsugune sotsiaalse mälu taust ja inforuum (rida 2.9, tsitaat E20), siis valdavalt eesti emakeelega õpilasi õpetav õpetaja mainis pigem nõukogude aja kujutlemise kognitiivset keerukust (rida 2.9, tsitaat E15). Sisuliselt tuli just venekeelseid õpilasi õpetavate osalejate vastustest välja Eesti praeguse ühiskonna olemuse ja mitte-eestlaste praeguse positsiooni tajutud valulikkus (rida 2.11).

Eesti identiteediga laiemalt seotud teemad ja põhjendused esinesid vastustes seevastu vaid mõnel korral. Eesti rahvusliku narratiivi keskmes olevateks, n-ö otseselt just Eesti identiteedile keskenduvateks teemadeks olid kõige selgemalt Vabadussõda ja Tartu rahu (mainitud kolm korda). Eestlaste identiteedi tähtsusele ajalooõpetuses osutab ka eestlaste perspektiivi domineerimine teatud teemade käsitlemisel, näiteks hariduse venestamise versus eestistamise küsimuses, millest oli juttu eespool. Ka teemad, mida tajutakse mingil põhjusel liiga vähe tähelepanu leidvatena või suisa ühiskondlike tabuteemadena mitte-eestlaste rolli tajutud märkamata jäämine, vapside liikumine ja Pätsi tegevus, koostöö sakslastega -, osutavad identiteediga seotud valukohtadele. 
Võib arvata, et avatud diskussioonide vähesus viitab samuti kas nende teemade identiteeditundlikkusele või siis poliitilistele probleemidele ja Eesti rahvusvahelisele näole.

Eestikeelses infoväljas ei ole piisavalt avatud/avameelseid arutelusid tundlike teemade üle. Isegi rahvusvahelistel konverentsidel on Eestil kui korraldajal hirm professionaalide avatud arutelude ees. (R2)

Konkreetsetest sündmustest või ajastutest, mida õpetajad ise esile tõid, olid Teise maailmasõja aastad konkurentsitul esikohal (tabeli read 2.5 ja 2.6, vrd eespool joonis 1). Midagi selle ajaga haakuvat tõi spontaanselt välja enamik vastajaid. Kolmandik kõigist vastajatest nimetas seda teemat üldiselt ning teine kolmandik mainis mõnda sellesse perioodi paigutuvat sündmust või küsimust - näiteks eestlaste osalemist Saksa sõjaväes või Punaarmee rolli võidu saavutamisel -, mis ei seostunud 1939.-1940. aasta sündmustega Eestis. Viimaseid mainisid ligi pooled vastajad (17). Õpetajate nimetatud tundlikud aspektid saab jagada kolme gruppi.

- Julmus, vägivald, genotsiid ja holokaust on emotsionaalselt rängad aspektid (tabeli rida 1.1), mida tajutakse tundlikuna kõigis uuritud Euroopa riikides. Holokaust on olnud ka politiseeritud teema, mida Eestis on tajutud väljast pealesurutuna (nt Pääbo, 2015; Stevick, 2007). Seega võib eestlaste osalus olla tundlik küsimus ühtaegu õpilaste kui oma-rühma perspektiivist ja ühiskondliku konteksti tõttu, milles tajutakse seda pealesurutava lähenemisviisina. Samuti mainiti õpilaste antisemiitlikke märkusi klassiruumis ning eestlaste osalust muudes sõjaaegsetes julmustes (nt Omakaitse raames) kui Eestis pigem mahavaikitud teemat.

- Kollaboratsionism on n-ö universaalselt tundlik teema - Euroopas vähemalt juhul, kui peetakse silmas koostööd natsivõimudega. Eestis paigutub siia ka koostöö nõukogude võimuga näiteks küüditamise teema kaudu (rida 2.8).

- Eesti annekteerimine 1940. aastal ja nõukogude võimu taastamine 1944. aastal ning osalemine teineteise vastu võitlevates armeedes ja erinevad hinnangud Teise maailmasõja osalistele on kaks kaks teada-tuntult tundlikku teemat, mis seostuvad samuti Teise maailmasõja aastatega.

Õpilaste identiteet polnud aga teema tundlikkust rõhutav aspekt mitte ainult ennast venelastena identifitseerivate õpilaste puhul. Olenevalt õpilaste päritolust võisid tundlikuks osutuda ka muud teemad, näiteks armeenlaste genotsiidi teema aserbaidžaani õpilase jaoks (vrd ülal ohvri ja süüdlase grupi eristamine) või kristluse teema Jehoova tunnistajast õpilase jaoks (tabeli rida 1.5 , vt eespool). Teisalt nimetati võimalusena õpilaste „esinemist“, teatud positsiooni võtmist - võimalik, et provotseerimiseks. Seda mainiti näiteks antisemiitlike (E16), aga ka rahvuslike ja immigratsioonivaenulike seisukohtade 
puhul (E2). Seejuures on õpilaste perekond ja kogukond huvitav tundlikkuse tekitaja, kuna see sisaldab aspekte alates perekondlikest mälestustest ja pereliikmete otsesest osalusest vaadeldavais sündmusis. Näiteks on maakooli õpilaste hulgas nii küüditajate kui ka küüditavate järeltulijaid ning mõlemad on kohalikele inimestele teada (rida 2.8, tsitaat E4). Pole üllatav, et mainiti ka Nõukogude ja Saksa armees sõdinute olemasolu perekonnas (rida 2.6) ja seost metsavendadega (rida 2.7).

Omaette küsimuste plokis lasime osalejatel hinnata võimalikke põhjuseid, mis võiks ühe või teise teema tundlikuks muuta. Palusime neil kirjutada ka teema, mille käsitlemist nad kaalusid, kuid mille õpetamisest kas loobusid või mille suhtes tundsid end ebakindlalt. Selle lisatingimuse tõttu vastas küsimuseplokile 18 õpetajat, kümme neist märkis mõne tundlikkuse põhjuse. Sagedamini mainitud teemade kohta annab ülevaate joonis 2, mis kinnitab spontaansetest vastustest ilmnenut: kõige sagedamini viidatakse teema tundlikkusele ühiskonnas ning kartusele riivata kellegi tundeid. Teisest küljest torkab silma väliste tegurite väike osakaal (mure lapsevanemate, kolleegide ja õppejuhataja võimaliku reaktsiooni pärast).



Joonis 2. Plokis "Pidasin seda teemat tundlikuks, kuna ..." vastusevariantidega "pigem jah" või „just sel põhjusel” nõustujate arv väidete kaupa ( $N=10$, absoluutarvud). Teemad, mida vastamisel silmas peeti: Teine maailmasõda ja/või eestlastevenelaste suhetega seotud teemad (6), pagulaste temaatika (2), naistevastane vägivald (1), mainimata (1) 
Kümnest kuuele õpetajale tundus teema ka isiklikult emotsionaalselt raske ning neljale tegi muret kahtlus, kas nad suudavad teemat käsitledes jääda erapooletuks. Avatud vastuste hulgas selliseid, mis avanuks ópetaja enda emotsioonide või isiklike kogemuste mõju mingi teema käsitlemisele, siiski ei olnud. Võimalik, et ankeet tervikuna suunas nimetama pigem sotsiaalseid, vastaja meelest üldistatavamaid aspekte. Siiski kajastus mõnes vastuses ebamugavus, ebakindlus või piinlikkustunne, mis õpetajaid teatud teemade käsitlemisel saadab. Osava, ettevaatliku ja taktitundelise lähenemise vajadust, sõnade valimist ja tavalisest enamat seletamist hõlmasid mitmed vastused. Põhjenduseks toodi aga pigem õpilaste emotsionaalne seotus (vt näiteid tabelis 2).

\section{Kuidas tundlikke teemasid käsitleda? Võimalused ja vajadused}

Vastates küsimusele tundlike teemade puhul kasutatud õppemeetodite kohta ${ }^{8}$, pidasid õpetajad oma senise kogemuse põhjal sobivaimaks tööd mälestustega, õpikule vasturääkivate allikate kasutamist ja koolivälist õpet või pedagoogide kutsumist väljastpoolt kooli (joonis 4). Paljud uuringus osalejad olid proovinud ka vastandlike allikate kriitilist analüüsi ning kasutanud ilukirjandust, kuid osa neist polnud kindel, kuivõrd hästi need meetodid töötasid. Veidi vähem oli rollimängu õnnestumises kahtlejaid. Päris paljud osalejad olid tundlike teemade puhul kasutanud ka n-ö tavalist õpetamisviisi, st õpetanud õpiku ja frontaalse loengu abil, kuid nende meetodite sobivuses oli ka suhteliselt enam kahtlejaid. Huvitaval kombel olid kõige vähem kasutatud meetoditeks dokumentaalfilmide vaatamine ning õpilaste oma uurimistöö perekonnas. Võimalik, et mõlemad osutavad ajalistele piirangutele, millega õpetajad peavad oma tööd kavandades arvestama. Teisalt ei tohiks dokumentaalfilm võtta rohkem aega kui muuseumitund, mistõttu võib arvata, et viimase kasutegurit tajutakse märksa suuremana - või siis on puudus sobivast, õpilaste positsiooni ja tunnetega arvestavast filmimaterjalist.

Joonis 3 näitab, et üldisel tasandil - eri meetodite kasutamise kogemuse poolest - on vastanud õpetajate pedagoogiline repertuaar üpris mitmekesine. Ka osalejate täiendusõppesoovid osutavad, et puudust tuntakse kas teadmistest teatud teemade kohta või juhistest, kuidas rakendada olemasolevaid meetodeid konkreetsele temaatikale: vastusena küsimusele „Kas sooviksite saada (veel) mingisugust täienduskoolitust seoses tundlike teemadega? Kui jah, kirjeldage palun märksõnade abil“ (14 vastust) tõi viis vastajat välja Teise maailmasõja ja nõukogude ajaga seotud teemad (küüditamisest nõukogude aja

Küsimus „Kuivõrd sageli olete (potentsiaalselt) tundlikku ajalooteemat õpetades kasutanud järgmisi meetodeid? Vastake palun just tundlike teemade õpetamise kohta, mitte õppemeetodite kasutamise kohta üldiselt". 
tähtsuseni) ja kolm vastajat tänapäevased sündmused, „et olla ajakirjandusest veidi ees“. Vaid kaks vastajat soovisid meetodikoolitust üldiselt.

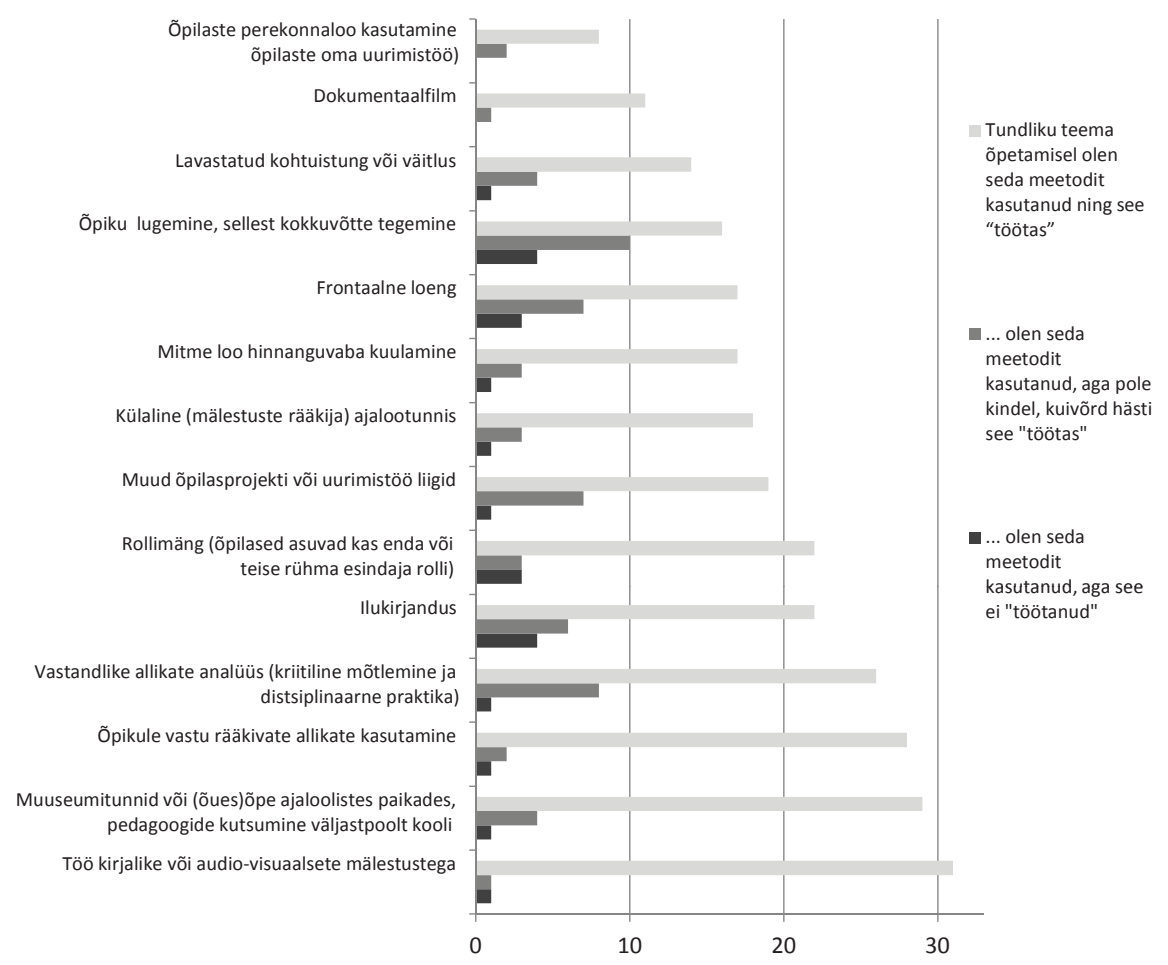

Joonis 3. Osalejate kogemused erinevate õppemeetoditega tundlike teemade käsitlemisel ( $N=37$, absoluutarvud)

Jooniselt 4 näeme, et õpetajad tunnevad ennast kõige kindlamalt siis, kui neil on nii küllaldaselt teemakohaseid teadmisi ja argumente kui ka sobivaid meetodeid ja õppematerjale. Kõige vähem nõustutakse väitega, et teemade tundlikkust vähendavad üldised suunised (õppekava), ehkki osa õpetajaid saab tuge sellestki. Võimalik, et silmas peeti siin õppekavas sisalduvat avatuse ja õpilastega arvestamise põhimõtet, mis võib õpetajat julgustada vastuoludega tegelema. Igatahes ilmneb jooniselt 4 õpetaja isikliku seisukoha ja pedagoogiliste ressursside - piisava hulga õppematerjalide, meetodite ja tehnikate, küllaldaste teadmiste ja heade argumentide - tähtsus. 


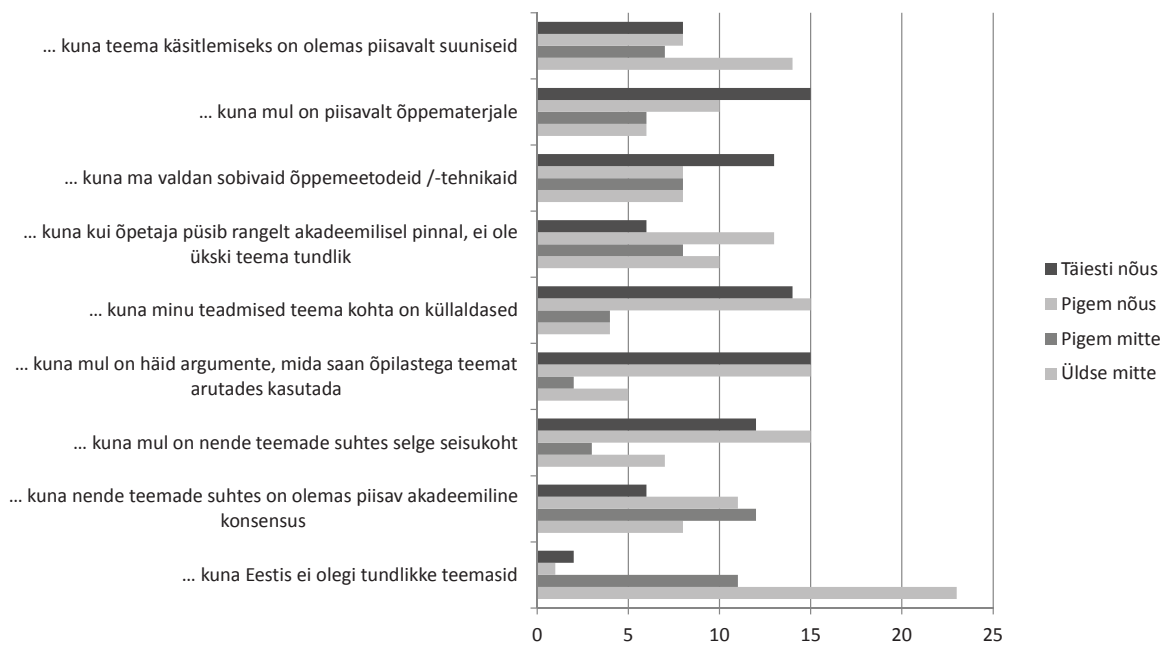

Joonis 4. Osalejate nõustumine väidetega potentsiaalselt tundlike teemade mittetundlikkuse võimalike põhjuste kohta: 1 - „üldse mitte“ / "ei nõustu esitatud väitega", 4 - „just sel põhjusel“ ( $N=37$, absoluutarvud)

\section{Tundlikkustaju seosed üldisemate arusaamadega ajalooõpetusest}

Nagu eespool märgitud, mõjutab nii teema tundlikkuse kui ka selle põhjuste tajumist kindlasti see, milliseid eesmärke ajalooõpetaja endale seab ning kuidas ta ajalooõpetust laiemalt näeb. Meie andmed võimaldavad välja tuua mõningaid suundumusi, mida oleks edaspidi vaja kontrollida suuremal valimil.

Käsitledes võimalikke ajalooõpetuse eesmärke, hindasid valimisse kuulunud õpetajad kõrgelt kõiki välja pakutud variante (joonis 5): skaala keskkoha $(2,5)$ lähedale ei langenud ühegi õppe-eesmärgi keskmine hinnang. Kõrgeima hinnangu pälvisid kriitilise mõtlemise ning argumentatsioonioskuste kujundamine, samuti teised pigem üldised eesmärgid, nagu demokraatlike väärtuste omaksvõtt, moraalsete vooruste arendamine ja õpilase isikliku identiteedi areng.

Hinnangute hajuvuse põhjal on näha, et ühiskonnakesksed eesmärgid tekitasid osalejates veidi enam vastakaid hinnanguid kui õpilaste üldistele oskustele ja isiklikule eneseteadvusele keskenduvad eesmärgid. Nimelt eristuvad paremaks kodanikuks saamine, rahvuslik või riiklik identiteet ning patriotism koos ajaloost meelelahutuse leidmise ja ajaloohuviga selle poolest, et kuigi enamik vastajaid nõustus ka nende eesmärkidega tugevalt, leidusid siiski mõned vastajad, kes neid eitasid (esines hinnanguid „1“või „0“).

Kõige üksmeelsemalt esikohale seatud eesmärkide põhjal võib oletada, et meie ankeedile vastasid õpetajad, kes tundlikku teemat kohates on huvitatud selle kasutamisest õpilaste kriitilise mõtlemise ja aruteluoskuse kujundamisel. 


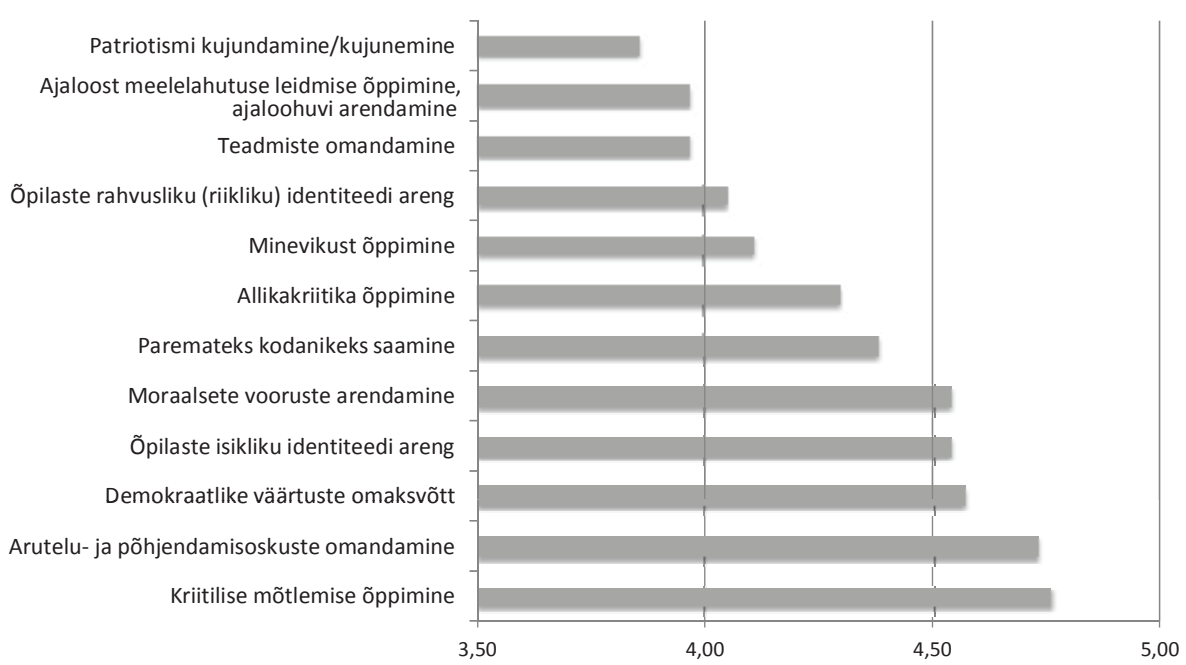

Joonis 5. Osalejate hinnangud ajalooõpetuse eesmärkidele: 0 - „ei ole üldse tähtis", 5 - „väga tähtis" ( $N=37$, keskväärtused)

Niisiis hindas enamik uuringus osalejaid väljapakutud eesmärke tähtsaks või väga tähtsaks. Vastuste faktoranalüüsi tulemusena eristus kolm eesmärgirühma: 1) õpilaste mõtlemise arendamine (allikakriitilisus, kriitiline mõtlemine, argumenteerimisoskused, minevikust õppimine); 2) ühiskonnakesksed eesmärgid (õpetada demokraatlikke väärtusi, kujundada kodanikutunnet, patriotismi ja/või riiklikku identiteeti) ning 3) õpilaste individuaalset arengut suunavad eesmärgid (toetada õpilase isiklikku identiteeti ja moraalseid väärtusi, anda teadmisi, arendada ajaloohuvi). Väikese valimi tõttu on raske õpetajaid nende tunnuste alusel rühmitada ning tõenäoliselt on nimetatud eesmärgid suuremal või vähemal määral esindatud kõigil õpetajatel. Nagu valimi kirjelduses märkisime, nõustusid osalejad eriti esimese rühma eesmärkidega peaaegu ühel häälel. Küll aga võime hüpoteetiliselt seostada eesmärke ja teema tundlikkuse olemust. Näiteks kui õpetamisel on esikohal ühiskonnakesksed eesmärgid ja riigi-identiteedi kujundamine, võidakse tajuda tundlikuna teemasid, milles ilmneb vaadete ja hinnangute lahknemine sellest, mida õpetajad tajuvad ühiskonnas domineeriva või ametliku (õppekavades, õpikutes, riigi tellitud esitustes parajasti valdava) arusaamana. Meie uurimuses on nendeks Teise maailmasõja ning nõukogude ajaga seotud teemad, mille puhul venekeelsete õpilaste ajalootõlgendus võib olla vastuolus õpikutes esitatuga. Kui õpetamise põhieesmärk on arendada eelkõige kriitilist mõtlemist, võib õpetaja püüda leida ja kasutada situatsiooni, mis arendaks õpilaste kriitilise mõtlemise ja arutlemisoskust ning võimaldaks tuua klassiruumi multiperspektiivsust (Stradling, 2005). 
Mul ei ole siiamaani olnud tundlikke teemasid. Mistahes tundlik teema on väljakutse, mis tekitab soovi kujundada oma arvamus antud sündmuse suhtes. (R4)

Mida tundlikum on teema, seda huvitavam tund. Teema võib olla tundlik, sest on päevakajaline, sest selle kohta on vastandlikke vaateid, sest neid teemasid on erinevalt esitatud eri inimestele. (R11)

Tähelepanu pööramine õpilaste identiteedist tulenevatele emotsioonidele on seotud eesmärgiga soodustada õpilase individuaalset arengut. Siin on oluline leida selline lähenemisviis, mis ei haavaks kellegi grupikuuluvusega seotud tundeid ega kahjustaks positiivset meie-kuvandit. Eestis tähendab see eelkõige venekeelse vähemuse positiivse kollektiivse identiteedi toetamist, hoolimata venelastele omistatud negatiivsest rollist Eesti ajaloos, millega seoses õpetajad osutasid vene õpilaste negatiivsetele tunnetele (vt näiteid tabelis 2, read 2.52.11). Kuidas selliste negatiivsete tunnetega toime tulla ning kujundada nende taustal riigi-identiteeti, ei ole ainult pedagoogiline, vaid ka poliitiline probleem.

Peale õppeainele seatavatest eesmärkidest sõltub tundlike teemade tajumine kindlasti ka sellest, kuidas näeb õpetaja ajalugu ja ajalooteadmisi laiemalt, millised on tema epistemoloogilised arusaamad. Kahest õpetajast, kes eitasid tundlike teemade olemasolu, oli üks vastaja üpris põhimõttelisel positsioonil („Jutt tundlikest teemadest on lihtsalt üks ajuvaba väljamõeldis") ning ta esitas mitmeid põhjendusi, mispärast ta tundlike teemade olemasolu eitab:

Kõik sõltub sellest, kuidas suhtub asjasse see, kes õpetab. [...] Asjadest tuleb lihtsalt rääkida ausalt ja avameelselt ning ilma ilustamata. See on ajalugu, st toimunud sündmused ning neid enam ei muuda (st sündmuste käiku). Kuidas aga antud teema serveeritakse, sõltub sellest, kes on riigis võimul ja missugune riigikord kehtib. [...] Mul ei ole olnud tundlikke teemasid, sest räägin kõigest nii, nagu see on. Kui vaja, siis ka toon välja vastaspoole seisukohad. Ajalugu on lugu toimunud sündmustest ning meie neid enam muuta ei saa. [...] Öelda mõne teema kohta „see on tundlik teema“ saab rääkida ainult see, kes antud teemal on ebakompetente antud valdkonnas. (E14)

Teine eitaja väljendus veidi tolerantsemalt:

Ajalooteemad ei ole tundlikud, kui seda hoolikalt läbi mõelda. Alati sõltub muidugi ka õpilastest ning nende päritolu peab arvestama. (E17)

Üks vastaja hoiatas:

Kui on soov õhutada vaenu Eestis elavate rahvaste vahel, siis võib selliseid teemasid leida igalt poolt. Ma arvan, et see ei ole koolide eesmärk ja õpilased tunnevad tihti ära ka selle, kui nende empaatiavõimet alahinnatakse. (E7) 
Üks vastaja selgitas:

[...] usun, et teoreetiliselt võivad kõik ajaloo teemad olla tundlikud/ omada mitut erinevat tõlgendust, oluline on õpetaja oskus vastuolusid märgata ja nendele klassiruumis tähelepanu pöörata/arutelu võimaldada ning teha seda lähtuvalt perspektiivist, et ajaloolist tõde ei ole olemas ja see on alati subjektiivne, olenedes kirjutaja rahvusest, poliitilisest motiveeritusest ja muudest faktoritest. Ajaloolise tõe asemel tuleks pigem rääkida ajaloolisest objektiivsusest, s.t. faktide ja teksti järelkontrollitavusest jne. (E18)

Viimati tsiteeritud õpetajate jaoks on tundlike teemade ennetajaks õpetaja kompetentsus (teema tundmine), teema eelnev läbimõtlemine ning mitmekülgne ja avameelne - ja/või õpilasi arvestav - selgitamine. Teatav positsioonierinevus ilmneb vastajate E14 ja E17 vastuste vahel. E14 vastus seab rõhuasetuse asjaolule, et minevikus toimunut ei saa enam muuta, samas kui E17 rõhutab vajadust mõelda toimunu käsitlemise viisi ja rõhuasetuste valikul õpilasele.

\section{Kokkuvõte}

Ajalugu on väärtuspõhine (Seixas, 2004), seega ka ideoloogiline ja poliitiline aine. Tundlike ja vastuoluliste teemade puhul ilmneb see tõsiasi eriti selgelt (nt Goldberg, 2016, 2017; Kello, 2016; Kello \& Wagner, 2017; Kitson \& McCully, 2005; Korostelina, 2015; Nakou \& Barca, 2010; Pääbo, 2011). Ei ole üllatav, et meie küsitluses olid sellisteks teemadeks esmajoones Eesti ajalooga seotud teemad, sealhulgas ennekõike sellised, mis seostusid Eesti ja Vene - või Eesti ja nõukogude - perspektiivide kokkupõrkega. Nende teemade tundlikkus tulenes mitmeti tõlgendatavusest ning Eesti ühiskonnas avatud ja kõigi osaliste perspektiive arvestava diskussiooni puudumisest. Hoolimata õppekava avatusest ja multiperspektiivsuse taotlusest kannavad ajalooõpetuse ühiskondlik kontekst, aga ka õpikud kui õppekava vahetuimad tõlgendused endiselt 1980ndate lõpus kujunenud paatost ning siinsete eestlaste ja venelaste mälukonflikti (vrd Oja, 2013; Pääbo, 2011; Raudsepp \& Makarova, 2017; Wulf, 2016). Eesti ajaloo ootuspäraselt tundlike aspektide kõrval tõid õpetajad välja ka teemasid, mis seostusid religiooni ja teiste etniliste rühmade konfliktidega minevikus. Osalt võib ka nende teemade puhul näha seoseid õpilaste praeguse ja siinse identiteediga - hoiakuga "meie siin“ versus "nemad seal“ näiteks islami ja muu religiooniga või koloniaalajalooga seotud teemade puhul. Laste jaoks raskete teemadena mainiti ka julmust ja vägivalda, eriti sõdades, laste osalust sõdades, sh Vabadussõjas, ning lapstööjõu kasutamist. Samuti osutati päevakajaliste, ajakirjanduses ja ühiskonnas teravalt vaieldavate teemade tundlikkusele. 
Kuidas õpetajaid toetada? Varasemad uuringud näitavad, kui tähtis on see, et õppekava võimaldaks aega ja süsteemset toetust, lähenemaks tundlikele teemadele paindlikult. Õpetajate ettevalmistuses tuleks pöörata rohkem tähelepanu õpetajate identiteedile, kuuluvusele ja n-ö välise surve tajumisele (vrd Kello \& Harro-Loit, 2012; Zembylas \& Kambani, 2012), aga ka ajalooteadvuse eri tüüpidele ja nende arengule (Rüsen, 2004). Meie küsitlusest võib järeldada, et õpetajatele oleksid toeks just konkreetse teemaga seotud teadmisi, argumente ja meetodeid tutvustavad ning nende üle arutlemist - koos õpetaja enda positsiooni selgitamisega - võimaldavad koolitused. Kuna on teada õpetajate suur töökoormus ja ainekava tihedus, mis piiravad võimalusi koolitustel pakutud meetodeid ja teadmisi paindlikult ja sobivalt kohandada, peaks võimalik täienduskoolituse formaat sisaldama paindliku rakendamise ja meetodi modifitseerimise võimalusi.

Kasu võib olla teiste riikide, näiteks Põhja-Iirimaa kogemusest ja eeskujust (nt Euroclio, 2013; Hess, 2009; McCully, 2005; Stradling, 2005). Mitmeperspektiivne ja konkreetseid õpilasi arvestav õpetamisviis on ilmselt miski, millest tundlike teemade käsitlemisel mööda ei saa. Õpetaja peaks lähenema käsitletavale teemale võimalikult avatult ja paindlikult, pidades samas silmas, et nurkade silumisest ei pruugi olla kasu. Nagu osutab Barton (2009), pole mõtet loota, et õpilased loobuksid ajaloo tõlgendamisest oma identiteedi alusel või ajaloo kasutamisest oma identiteedi kujundamisel pelgalt seetõttu, et nad ei kohta sobivat käsitlusviisi koolis. Küll aga võib identiteeditöös üksi jäetud õpilase mõttetegevuse tulemus olla piiratum ning toetuda ühiskonda lõhestavatele allikatele. Seetõttu tuleks Bartoni arvates toetada identiteete, mis on „pigem komplekssed, mitmekesised ja kaasavad kui lihtsad, monoliitsed ja välistavad“ (lk 275). Seda järeldust ei pruugi kanda üle ainult Eesti ühiskonda juba teada-tuntult lõhestavatele ajalooteemadele, vaid seda võib laiendada ka muudele tundlikele teemadele, nt sõjad ja vägivald või maailma ebaõiglus ja korruptsioon, mida meie uuringus osalejad samuti mainisid. Samal ajal, arvestades emotsionaalset keerukust ja laste vanust, ei pruugi ka mõnest aspektist vaikimine olla igal konkreetsel juhul vale valik - siin tulebki usaldada õpetaja professionaalset tunnetust.

Hoolimata mitmesuguste soovituste olemasolust on haridusuuringud ja psühholoogiateadus eri kontekstides ja eri õpilaste puhul sobivate meetodite ning eri meetodite sobivuskriteeriumite - soovitamisest veel pigem kaugel. Ei emotsionaalselt keerukad teemad (nt inimeste julmus, vägivald), eriti seoses kollektiivse identiteedi ja poliitilise survega, ega selliste aspektide eakohaste käsitlusviiside uurimine pole seni olnud psühholoogiauuringute keskmes. Seetõttu nõuab probleemsete küsimustega tegelemine õpetajalt julgust, algatusvõimet ja leidlikkust. Õpilaste arusaamade lähem uurimine just ajalooõpetuse 
kontekstis on tähtis eelseisev uurimisvajadus, millele praegusel juhul tuleb osutada. Nagu sedastas ka üks siinses uuringus osalenu, võivad õpilaste arusaamad olla märksa mitmekesisemad ja keerukamad, kui õpetajad seda tajuvad (vrd Barton \& McCully, 2005).

Kokkuvõttes võib öelda, et kuigi tundlikke teemasid tuleb ette paljudes óppeainetes, on ajaloo eripäraks tihe seos sotsiaalse identiteedi süvakihtidega. Minevikus toimunu tuletab meelde asjaosaliste rühmakuuluvust ning võib kutsuda esile tugevaid emotsioone: nii rõõmsaid ja uhkeid kui ka valusaid ja vaenulikke. Küsimusi, mis seostuvad õpilastele ja õpetajatele lähedaste inimrühmade identiteedi ning juurdunud veendumustega, ei saa lahata samal viisil nagu akadeemiliselt vaieldavaid või ühiskonnas vastuolulisi, kuid õpilasi isiklikult vähem puudutavaid küsimusi. See muudab ajaloo õpetamise keeruliseks, ent ka huvitavaks ja väljakutseid pakkuvaks, eriti ajalooteadvuse dialogismi ja vastastikulisuse (Kivimäe, 2000) seisukohast.

\section{Tänusõnad}

Täname kõiki küsitluses osalenud õpetajaid. Uuringut toetasid Euroopa Liit koostöövõrgustiku COST (Action IS 1205 „Ajaloo representatsioonide sotsiaalpsühholoogiline dünaamika laienenud Euroopa Liidus") kaudu ning Haridus- ja Teadusministeerium institutsionaalse uurimistoetuse IUT 20-38 kaudu.

\section{Kasutatud kirjandus}

Bar-Tal, D., Chernyak-Hai, L., Schori, N., \& Gundar, A. (2009). A sense of self-perceived collective victimhood in intractable conflicts. International Review of the Red Cross, 91(874), 229-258. https://doi.org/10.1017/S1816383109990221

Barton, K. C. (2009). The denial of the desire. How to make history education meaningless. In L. Symcox \& A. Wilschut (Eds.), National history standards: The problem of the canon and the future of teaching history (pp. 265-282). Charlotte: Information Age Publishing.

Barton, K. C., \& McCully, A. W. (2005). History, identity, and the school curriculum in Northern Ireland: An empirical study of secondary students' ideas and perspectives. Journal of Curriculum Studies, 37(1), 85-116.

https://doi.org/10.1080/0022027032000266070

Bilewicz, M., \& Stefaniak, A. (2013). Can a victim be responsible? Antisemitic consequences of victimhood-based identity and competitive victimhood in Poland. In B. Bokus (Ed.), Responsibility: An interdisciplinary perspective. Warsaw: Lexem.

Braun, V., \& Clarke, V. (2006). Using thematic analysis in psychology. Qualitative Research in Psychology, 3(2), 77-101. https://doi.org/10.1191/1478088706qp063oa 
Cooper, H., \& Nichol, J. (Eds.) (2015). Identity, trauma, sensitive and controversial issues in the teaching of history. Newcastle upon Tyne: Cambridge Scholars Publishing.

Euroclio (2013). Manifesto on high quality history, heritage and citizenship education. 15 principles for recognition of the distinctive contribution of history to the development of young people. Retrieved from http://euroclio.eu/2015/12/euroclio-manifesto-high-quality-history-education-now-available-7-languages/.

Goldberg, T. (2016). Increasing understanding or undermining national heritage: Studying single and multiple perspectives of a formative historical conflict. In C. van Boxtel, M. Grever, \& S. Klein (Eds.), Sensitive pasts: Questioning heritage in education (pp. 240-260). New York, Oxford: Berghahn Books.

Goldberg, T. (2017). The official, the empathetic, and the critical: Three approaches to history teaching and reconciliation in Israel. In C. Psaltis, M. Carretero, \& S. Čehajić-Clancy (Eds.), History education and conflict transformation: Social psychological theories, history teaching and reconciliation (pp. 277-299). Palgrave Macmillan. https://doi.org/10.1007/978-3-319-54681-0_11

Goldberg, T., Schwartz, B. B., \& Porat, D. (2011). "Could they do it differently?": Narrative and argumentative changes in students' writing following discussion of "hot" historical issues. Cognition and Instruction, 29(2), 185-217. https://doi.org/10.1080/07370008.2011.556832

Hawkey, K., \& Prior, J. (2011). History, memory cultures and meaning in the classroom. Journal of Curriculum Studies, 43(2), 231-247. https://doi.org/10.1080/00220272.2010.516022

Hess, D. E. (2009). Controversy in the classroom: The democratic power of discussion. New York: Routledge.

Imhoff, R., Bilewicz, M., \& Erb, H.-P. (2012). Collective regret versus collective guilt: Different emotional reactions to historical atrocities. European Journal of Social Psychology, 42(6), 729-742. https://doi.org/10.1002/ejsp.1886

Journell, W. (2013). Learning from each other: What social studies can learn from the controversy surrounding the teaching of evolution in science. The Curriculum Journal, 24(4), 494- 510. https://doi.org/10.1080/09585176.2013.801780

Kello, K. (2016). Sensitive and controversial issues in the classroom: Teaching history in a divided society. Teachers and Teaching: Theory and Practice, 22(1), 35-53. https://doi.org/10.1080/13540602.2015.1023027

Kello, K., \& Harro-Loit, H. (2012). Recognising dilemmas in history teaching - a tool for increasing teacher's autonomy. In J. Mikk, M. Veisson, \& P. Luik (Eds.), Lifelong learning and teacher development. Estonian studies in education 4 (pp. 113129). Frankfurt am Main etc.: Peter Lang Verlag.

Kello, K., \& Wagner, W. (2017). History teaching as 'propaganda'? Teachers' communication styles in post-transition societies. In C. Psaltis, M. Carretero, \& S. Čehajić-Clancy (Eds.), History education and conflict transformation: Social psychological theories, history teaching and reconciliation (pp. 201-230). Palgrave Macmillan. https://doi.org/10.1007/978-3-319-54681-0_8

Kitson, A., \& McCully, A. (2005). "You hear about it for real in school." Avoiding, containing and risk-taking in the history classroom. Teaching History, 120, 32-37. 
Kivimäe, M. (2000). Ajaloomõtlemise kolm strateegiat ja nende dialoogisuhted minevikuga. Tallinn: Tallinna Pedagoogikaülikool.

Korostelina, K. (2015). Reproduction of conflict in history teaching in Ukraine: A social identity theory analysis. Identity, 15(3), 221-240. https://doi.org/10.1080/15283488.2015.1057283

McCully, A. (2005). Teaching controversial issues in a divided society: Learning from Northern Ireland. Prospero, 11(4), 38-46.

Nakou, I., \& Barca, I. (Eds.) (2010). Contemporary public debates over history education. Charlotte: Information Age Publishing.

Oja, M. (2013). The image of the other in the history of Estonia on the basis of contemporary textbook analysis. Yearbook 2013 - International Society for History Didactics, 34, 57-72.

Oja, M. (2016). Muutused üldhariduskooli ajalooõpetuses alates 1987. aastast - nõukogulikust tänapäevaseks (doktoritöö). Tallinn: Tallinna Ülikool.

Pääbo, H. (2011). Potential of collective memory based international identity conflicts in post-imperial space: Comparison of Russian master narrative with Estonian, Ukrainian and Georgian master narratives. Tartu: Tartu Ülikooli Kirjastus.

Pääbo, H. (2015). Holocaust and the collective memory in Estonia. In E. Smolar (Ed.), Memory and responsibility. The legacy of Jan Karski (pp. 174-181). Warsaw: Semper Scientific Publisher.

Rantala, J. (2011). Children as consumers of historical culture in Finland. Journal of Curriculum Studies, 43(4), 493-506. https://doi.org/10.1080/00220272.2011.584563

Raudsepp, M., \& Makarova, M. (2017, in press). Identity and intergroup positioning in relation to the common past. In R. Vetik (Ed.), Determinants of inclusive intergroup context: Acculturation trends in Estonia and beyond. Routledge.

Rüsen, J. (2004). Historical consciousness: Narrative structure, moral function, and ontogenetic development. In P. Seixas (Ed.), Theorizing historical consciousness (pp. 63-85). Toronto: University of Toronto Press.

Seixas, P. (2004). Introduction. In P. Seixas (Ed.), Theorizing historical consciousness (pp. 3-20). Toronto: University of Toronto Press.

Stevick, E. D. (2007). The politics of the Holocaust in Estonia: Historical memory and social divisions in Estonian education. In E. D. Stevick \& B. A. U. Levinson (Eds.), Reimagining civic education: How diverse societies form democratic citizens (pp. 217-244). Lanham: Rowman and Littlefield.

Stradling, R. (2005). Multiperspektiivsus ajaloo õpetamisel. Teejuht ópetajale. Tallinn: Koolibri.

Zembylas, M., \& Kambani, F. (2012). The teaching of controversial issues during elementary-level history instruction: Greek-Cypriot teachers' perceptions and emotions. Theory \& Research in Social Education, 40(2), 107-133. https://doi.org/10.1080/00933104.2012.670591

Tulviste, P. (1994). History taught at school versus history discovered at home: The case of Estonia. European Journal of Psychology of Education, 9(2), 121-126. https://doi.org/10.1007/BF03173547

Wulf, M. (2016). Shadowlands. Memory and history in post-Soviet Estonia. New York: Berghahn. 


\title{
If that's the goal, any topic can be sensitive? Estonian teachers' experiences with sensitive issues in history
}

\author{
Katrin Kello ${ }^{\text {la }}$, Maaris Raudsepp ${ }^{\mathrm{b}}$ \\ ${ }^{a}$ Institute of Social Studies, University of Tartu \\ ${ }^{b}$ School of Governance, Law and Society, Tallinn University
}

\begin{abstract}
Summary
Societally sensitive content is one of the challenges of the teaching profession. In history and social studies, such content is often related to political controversies and painful historical experiences. The present paper reports on a survey among teachers on "Sensitive issues and political interests in history teaching". The survey was part of an international collaborative project "Social psychological dynamics of representations of history in the enlarged European Union" (COST network). The survey focused on sensitive issues in a broad sense, letting the respondents define sensitivity themselves. The teachers were asked closed and open questions to point out and assess possibly sensitive issues encountered during their teaching experience, the reasons for sensitivity and the factors affecting sensitivity. Contextual factors and the respondents' beliefs about history teaching were also enquired about. In Estonia, the webbased questionnaire was made available to fill in either in Estonian or Russian language.

In this paper, we present the findings from the Estonian data. We depart from the research on teaching sensitive and controversial issues in social studies and history teaching, as well as from the social psychology literature about dealing with troubled pasts. We analyse which issues are perceived as sensitive by Estonian teachers and why, which strategies are used for teaching these topics, and what kind of support the teachers need. We also analyse what external factors they perceive as influencing history teaching and discuss how perceiving and teaching sensitive issues may be related to the aims and goals of history teaching that teachers value. We use thematic content analysis of open answers, as well as descriptive statistics. The results are discussed in the framework of multi-perspective history teaching, teachers' autonomy and societal context of history teaching.
\end{abstract}

Institute of Social Studies, University of Tartu; Lossi 36, 51003 Tartu, Estonia; katrin.kello@ut.ee 
The prevalent reason for sensitivity was the social and political sensitivity of an issue and more particularly, the different perspectives on an historical event by social memory groups and/or in textbooks, Estonian and Russian media and official positions.

The most frequently mentioned issues were, on one hand, current issues such as the refugee issue and on-going wars. The history of Islam as related to terrorism and possibly the refugee crisis, or wars in Ukraine and Syria, belong to this category.

On the other hand, most of the teachers mentioned issues related to Russian-speaking students in their classrooms. In fact, the majority of sensitive topics mentioned by the teachers refer to events and processes related to Russian and Soviet dominance in Estonia.

The following topics prevailed: WW2 (including war crimes, Holocaust; mainly related to Estonia); events in 1939/1940 and/or 1944 (Soviet occupation) in Estonia; The Soviet era; late 1980s; dissolution of the Soviet Union and restoring Estonian Independence; Estonian society since 1991; the position of the Russian speaking minority - and related to this, the Russification policy in the late 19th century and during the Soviet era, as well as the role of Russia or Russians in Estonian history more generally.

The period of WW2 and related events have been the sensitive issues par excellence in Estonia - our teachers' responses confirm this. One third of all participants mentioned the time of WW2 in general and an additional third mentioned specific aspects of WW2. Closely related to WW2 are the events of $1939 / 40$ and 1944. Both dates refer to the annexation of Estonia by the USSR. Either of the events or both were spontaneously mentioned by almost one half of the teachers. The more specific aspects mentioned were (1) cruelty, violence, genocide, Holocaust; (2) collaboration (with either side); (3) the meaning of annexation of Estonia to the Soviet Union in 1940 and 1944, and the appropriateness of using the term 'occupation' for this; (4) Estonians fighting in both the Soviet and the German army and the 'relative representation' of this in the textbooks and Estonian public spaces.

The reason for sensitivity often derived from students, their families and communities. Collective memories and general worldviews, as well as direct personal involvement, were mentioned here. For example, the fact that "among students, there are descendants of both those who deported and the deportees, and local people know people from several generations" was mentioned. Students' emotions and cognitive difficulties related to sensitivity appeared when events were emotionally laden or the students' in-group appeared in a negative light. Several teachers also mentioned sensitivity deriving from ambiguousness, 
lack of clarity and openness (lack of open, professional discussions), as well as sensitivity deriving from flaws or bias in textbooks.

Interestingly, there were no responses directly and explicitly referring to the teacher as a source of an issues' sensitivity among the open answers - such as personal or family experiences, being unsure about their own position or lack of knowledge. However, an uneasy or awkward feeling was reflected in some of the open responses where teachers explained why and how some issues were sensitive.

In short, our findings highlight the heat of the social and political contexts of Estonian history teaching, and the clear differences between the challenges faced by teachers who work with Russian-speaking students or in mixed Estonian-Russian classrooms, as opposed to Estonian-only settings. The presence of conflicting social and, indeed, political memories in the classroom clearly actualises the potential sensitivity of topics related to the Estonian and Russian common past. However, apart from issues related to the local troubled past, many teachers also mentioned current and global issues, or issues generally related to violence, cruelty, or 'corruption in the world'.

With both kinds of topics, there are no universal recipes as to which teaching strategies might be 'the best' in each particular situation: there may be benefits and disadvantages in both 'smoothing edges', 'taking the risk' or approaching an issue openly. However, as Barton (2009) warns us with regard to issues that are relevant to the students' identities, there are certain issues that students are interested in anyway, and on which they will form their own opinion, whether they learn about it in school or not: if educators avoid those issues, they do so at their own peril.

We can conclude that teaching sensitive issues demands a lot from the teacher - a sense of tact as well as skills and resourcefulness. It is a complicated challenge, but also an intriguing and potentially rewarding one that may open up new professional avenues.

Keywords: history teaching, teachers, identity, sensitive issues, social memory, socio-political contexts of education 